\title{
ANALISIS DAYA DUKUNG LAHAN DI KAWASAN PUNCAK KABUPATEN BOGOR
}

\author{
Analysis of Land Carrying Capacity in Puncak Area, Bogor District \\ Yunita Lisnawati dan/and Ari Wibowo \\ Pusat Penelitian dan Pengembangan Hutan Tanaman \\ Kampus Balitbang Kehutanan, J1. Gunung Batu No. 5, Bogor 16610 \\ Telp. (0251) 8631238, Fax. (0251) 7520005 \\ Naskah masuk : 5 Pebruari 2008 ; Naskah diterima : 16 Januari 2009
}

\begin{abstract}
Puncak area of Bogor District has been assigned as special area, soil and water conservation area, tourism area and buffer area of capital city of Jakarta. Land use in this area has changed quite dramatically, particularly due to conversion of agricultural lands to non-agricultural lands that lead to lower land carrying capacity. This study was aimed to analyze land carrying capacity of Puncak Area in 2005. Land carrying capacity is defined as number of population that can be supported and accommodated by available land resources using current agricultural practices and technology without leading to land degradation. Analysis was carried out using Bayliss-Smith formula represented by tree villages namely Gadog, Batulayang, and Sukakarya. This study found that land carrying capacity of the tree villages in Puncak area namely Gadog, Batulayang, and Sukakarya in 2005 were 53.65,40.90 and 84.48 people/ha respectively. As the current population density of the three villages were $36.05,26.61$, and 14,71 people/ha respectively, this meant that only Gadog village has exceeded its land carrying capacity.
\end{abstract}

Keywords: land carrying capacity, Puncak area

\begin{abstract}
ABSTRAK
Kawasan Puncak di Kabupaten Bogor telah ditetapkan sebagai kawasan andalan, kawasan konservasi tanah dan air, daerah wisata dan penyangga ibu kota Jakarta. Akan tetapi kawasan ini telah mengalami banyak perubahan penggunaan lahan yang mempersempit lahan pertanian dan dapat menurunkan daya dukung lahan. Penelitian ini bertujuan untuk menganalisis besarnya daya dukung lahan di kawasan Puncak Kabupaten Bogor pada tahun 2005. Daya dukung lahan adalah jumlah penduduk yang dapat didukung atau disokong oleh suatu luas sumberdaya lahan pada lingkungan tertentu dalam keadaan makmur, sesuai dengan teknologi dan pengelolaan usahatani yang dilakukan petani. Analisis dilakukan dengan menggunakan rumus Bayliss-Smith yang diwakili oleh 3 desa contoh yaitu desa Gadog, Batulayang dan Sukakarya. Hasil perhitungan daya dukung menunjukkan daya dukung lahan di desa Sukakarya 84,48 jiwa/ha, desa Batulayang 40,90 jiwa/ha dan desa Gadog sebesar 35,65 jiwa/ha. Dengan angka kepadatan penduduk yang sesungguhnya yaitu desa Sukakarya 14,71 jiwa/ha, Batulayang 26,61 jiwa/ha dan Gadog 36,05 jiwa/ha, maka diketahui bahwa desa Gadog sudah melampaui daya dukung lahannya.
\end{abstract}

Kata Kunci : daya dukung lahan, kawasan Puncak 


\section{PENDAHULUAN}

\section{A. Latar Belakang}

Lahan merupakan sumberdaya pembangunan yang memiliki luas relatif tetap dan memiliki sifat fisik tertentu yang dapat menampung kegiatan masyarakat. Oleh karena itu, lahan perlu diarahkan untuk dimanfaatkan yang paling sesuai dengan sifat fisiknya serta dikelola agar mampu menampung kegiatan masyarakat yang terus berkembang. Secara berkelanjutan dengan adanya pertambahan penduduk dan peningkatan pembangunan di berbagai bidang, sering terjadi terlampauinya daya dukung lahan sehingga mengarah pada eksploitasi sumberdaya alam yang lain seperti sumberdaya hutan. Daya dukung lahan adalah jumlah penduduk yang dapat didukung atau disokong oleh suatu luas sumberdaya lahan pada lingkungan tertentu dalam keadaan makmur, sesuai dengan teknologi dan pengelolaan usahatani yang dilakukan petani (Soerianegara, 1978). Perhatian terhadap daya dukung merupakan kunci bagi perwujudan ruang hidup yang nyaman dan berkelanjutan.

Peningkatan jumlah penduduk telah mengakibatkan terjadinya pengolahan lahan sampai ke tebing-tebing dan terjadinya penyusutan luas lahan (Jones, 1993 dalam Rusli, 1997). Hal tersebut mengakibatkan terjadinya erosi yang selanjutnya mengakibatkan pendangkalan sungai, sehingga bila datang hujan seringkali menimbulkan banjir. Erosi juga menyebabkan pengendapan lumpur pada dam-dam yang dapat mempersingkat umur dam tersebut. Penurunan daya dukung lahan disamping disebabkan oleh peningkatan jumlah penduduk, salah satunya juga disebabkan oleh adanya konversi lahan. Konversi lahan pertanian produktif menjadi lahan non pertanian secara nasional telah mencapai 35.000 hektar per tahun. Khusus untuk lahan pertanian beririgasi di Pulau Jawa, laju alih fungsinya telah mencapai 13.400 hektar per tahun yang dapat mengancam ketahanan pangan nasional dan mengganggu keseimbangan lingkungan (Hermanto, 2005).

Kawasan Puncak dalam Rencana Tata Ruang Wilayah Nasional (RTRWN) ditetapkan sebagai kawasan andalan yang berperan untuk mendorong pertumbuhan ekonomi bagi kawasan itu sendiri dan kawasan sekitarnya serta dapat mewujudkan pemerataan pemanfaatan ruang. Puncak juga ditetapkan sebagai kawasan yang mempunyai nilai strategis sehingga penataan ruangnya diprioritaskan. Selain itu, Puncak adalah juga ditetapkan sebagai kawasan pariwisata, kawasan konservasi tanah dan air, dan kawasan penyangga DKI Jakarta (Pemerintah Kabupaten Daerah Tingkat II Bogor, 2000). Kawasan Puncak memiliki berbagai fungsi, namun demikian tata guna lahannya sudah mengalami banyak perubahan. Pesatnya perubahan penggunaan lahan dipengaruhi oleh faktor sosial seperti peningkatan jumlah dan kegiatan penduduk, kegiatan pariwisata, kemudahan akses oleh sarana transportasi dan dekatnya dengan pusat kota. Perubahan ini menyebabkan pergeseran penggunaan lahan menjadi kawasan pemukiman, industri dan kawasan terbangun lainnya, yang mempersempit lahan pertanian dan pada akhirnya menurunkan daya dukung lahan.

Penelitian ini bertujuan untuk menganalisis besarnya daya dukung lahan di kawasan Puncak Kabupaten Bogor. Hasil penelitian diharapkan dapat menjadi masukan bagi pembuat kebijakan untuk merencanakan kegiatan pembangunan di wilayah ini, sehingga kawasan Puncak yang telah ditetapkan sebagai kawasan andalan, kawasan konservasi tanah dan air, daerah wisata dan penyangga ibu kota Jakarta dapat dipertahankan kelestariannya.

\section{BAHAN DAN METODE}

\section{A. Tempat dan Waktu}

Penelitian dilakukan di kawasan Sub DAS Ciliwung Hulu yang terdiri dari tiga kecamatan yaitu Kecamatan Cisarua, Megamendung dan Ciawi. Data primer diambil dari 3 contoh yang banyak 
mengalami perubahan lahan, yaitu desa Batulayang, Sukakarya, dan Gadog. Penelitian dilaksanakan pada bulan Juli sampai dengan Oktober 2005.

\section{B. Pengumpulan Data}

Data yang dikumpulkan terdiri dari data primer dan data sekunder. Data primer diperoleh melalui survei secara langsung di 3 desa yaitu Batulayang, Sukakarya, dan Gadog untuk kegiatan wawancara dengan menggunakan kuesioner. Data sekunder diperoleh di kantor Pemerintah Daerah Tingkat II Kabupaten Bogor, Dinas Pertanian Tanaman Pangan, Pemerintah Kecamatan Cisarua, Megamendung dan Ciawi, serta instansi yang menunjang tercapainya tujuan penelitian.

Penentuan lokasi penelitian dan petani responden dilakukan secara sengaja (purposive). Pemilihan atau penentuan desa-desa contoh dilakukan dengan cara pengambilan contoh secara sengaja, yaitu dengan memilih 3 desa yang paling banyak terjadi perubahan penggunaan lahannya dan tiap desa dipilih responden sebanyak 15 orang yang dilakukan secara acak dan telah mewakili $30 \%$ dari jumlah petani di masing-masing desa. Penentuan kepala keluarga contoh dilakukan berdasarkan kemudahan aksesibilitas petani responden.

Wawancara dengan responden dilakukan dengan menggunakan seperangkat daftar kuesioner yang telah dipersiapkan sebelumnya. Data sosial yang dikumpulkan antara lain : jumlah penduduk, pekerjaan, pendidikan, luas lahan garapan, jenis tanaman dan produksi, pendapatan usahatani dan pendapatan diluar usahatani. Pendapatan per kapita dihitung dari besarnya pengeluaran, baik dari usahatani maupun dari luar usahatani.

\section{Analisis Daya Dukung Lahan}

Untuk menganalisis daya dukung lahan digunakan rumus Bayliss-Smith (Soerianegara, 1978). Rumus ini belum menggambarkan adanya kegiatan dan pola konsumsi penduduk di luar pertanian. Agar hal tersebut tercermin pada besarnya daya dukung yang diperoleh, pada rumus Bayliss-Smith tersebut ditambahkan/dimasukkan faktor koreksi p dan k (Agustono, 1984) sehingga rumus menjadi :

$$
\mathrm{K}\left|\frac{\prod_{s i \mid 1}^{p} \mathrm{~A}_{\mathrm{si}} \cdot \mathrm{Y}_{\mathrm{si}}}{\prod_{s i \mid 1}^{1} \mathrm{C}_{\mathrm{si}}}\right| \frac{1}{\mathrm{R}} \mathrm{xp \times k}
$$

\section{Dimana :}

$\mathrm{K}=$ Daya dukung lahan (orang/ha)

$\mathrm{A}_{\mathrm{si}}=$ Luas lahan pertanian tanaman pangan si (ha)

$\mathrm{Y}_{\mathrm{si}}=$ Produktifitas bersih jenis tanaman pangan si (kkal/ha/tahun)

$\mathrm{C}_{\mathrm{si}}=$ Tingkat konsumsi minimum untuk masing-masing jenis tanaman pangan dalam menu penduduk (kkal keseluruhan)

$\mathrm{R}=$ Kebutuhan kalori rata-rata per orang dalam setahun(kkal/orang/tahun)

$\mathrm{p}=$ Faktor koreksi terhadap jumlah penduduk yang mempunyai mata pencaharian di luar sektor pertanian

$\mathrm{k}=$ Faktor koreksi terhadap konsumsi penduduk diluar sektor pertanian 
Besarnya nilai p dihitung dengan rumus :

$$
\mathrm{p} \mid \frac{\text { Jumlah penduduk yang bermata pencaharian }}{\text { Jumlah penduduk yang mempunyai mata pencaharian sektor pertanian }}
$$

Basarnya faktor $k$ dihitung dengan rumus :

$$
\mathrm{k} \mid \frac{\text { Jumlah pengeluaran non pangan }(\mathrm{Rp} / \mathrm{tahun})}{\text { Jumlah pengeluaran pangan }(\mathrm{Rp} / \text { tahun })}
$$

Besarnya nilai $\mathrm{p}$ ditentukan oleh jumlah penduduk yang bermata pencaharian dan jumlah penduduk yang mempunyai mata pencaharian di sektor pertanian. Sedangkan nilai k ditentukan oleh besarnya pengeluaran di luar sektor pertanian dan jumlah pengeluaran di sektor pertanian. Dengan demikian penambahan faktor koreksi $\mathrm{p}$ dan $\mathrm{k}$ ke dalam metode Bayliss-Smith, akan mempengaruhi besarnya daya dukung lahan $(\mathrm{K})$ yang diperoleh.

Untuk menghitung produksi bersih jenis-jenis tanaman pangan dan nilai kilo kalori (kkal) setiap tanaman yang akan diteliti, digunakan angka konversi dari Soedarmo dan Sediaoetama (1977), Direktorat Gizi Departemen Kesehatan RI (1979), serta Sajogyo et al., (1983) yaitu : padi = 40\%, jagung =65\%, umbi-umbian $=80 \%$, kacang-kacangan $=60 \%$ dan sayur-sayuran $=100 \%$. Sedangkan nilai kalori setiap kilogram jenis produksi adalah 3600 kkal untuk beras, 2300 kkal untuk jagung, 1400 kkal untuk umbiumbian, 3550 kkal untuk kacang-kacangan dan 330 kkal untuk sayur-sayuran Keperluan kalori setiap hari menurut Sayogyo et al. (1983) disajikan pada Tabel 1.

\begin{tabular}{|c|c|c|c|c|}
\hline \multirow[b]{2}{*}{$\begin{array}{l}\text { Golongan Umur } \\
\text { (Age Category) } \\
\text { (Tahun) } \\
\text { (Year) }\end{array}$} & \multicolumn{2}{|c|}{ Laki-laki (Male) } & \multicolumn{2}{|c|}{ Perempuan (Female) } \\
\hline & $\begin{array}{l}\text { Berat Badan } \\
(\text { Weight }) \\
(\mathrm{kg}) \\
\text { Orang/hari }\end{array}$ & $\begin{array}{c}\text { Keperluan Kalori } \\
\text { (Calorie need) } \\
\text { kg/hari } \\
\text { (kcal) }\end{array}$ & $\begin{array}{c}\text { Berat Badan } \\
(\text { Weight }) \\
(\mathrm{kg}) \\
\text { Org/hari }\end{array}$ & $\begin{array}{c}\text { Keperluan Kalori } \\
\text { (Calorie need) } \\
\text { kg/hari } \\
\text { (kcal) }\end{array}$ \\
\hline Kurang 1 & 8 & 900 & 8 & 900 \\
\hline $1-3$ & 12 & 1.200 & 12 & 1.200 \\
\hline $4-6$ & 18 & 1.650 & 18 & 1.650 \\
\hline $7-9$ & 27 & 2.100 & 27 & 2.100 \\
\hline $10-12$ & 35 & 2.500 & 35 & 2.200 \\
\hline $13-15$ & 42 & 2.400 & 42 & 2.100 \\
\hline $16-19$ & 50 & 2.450 & 45 & 1.950 \\
\hline Dewasa & 55 & 2.500 & 47 & 1.900 \\
\hline
\end{tabular}

Tabel (Table) 1. Keperluan tenaga (kalori) dalam sehari (Daily calorie consumption)

Sumber : Sajogyo et al. (1983).

Keperluan kalori ini sifatnya relatif, besarnya dipengaruhi berat atau ringannya pekerjaan setiap hari dan berat badan. Seorang laki-laki yang berat badannya $55 \mathrm{~kg}$ dan beban pekerjaan yang berat memerlukan kalori sebanyak 3.400 kkal. Dengan mempertimbangkan kebutuhan kalori seperti pada Tabel 1, maka dalam penelitian ini ditetapkan banyaknya kalori per kapita per hari adalah $2.400 \mathrm{kkal}$. Dengan demikian banyaknya kalori yang diperlukan dalam satu tahun adalah $365 \times 2.400 \mathrm{kkal} / \mathrm{kapita} / \mathrm{tahun}$ yaitu sebesar $876.000 \mathrm{kkal}$. 


\section{HASIL DAN PEMBAHASAN}

\section{A. Luas Lahan yang Ditanami Tanaman Pangan dan Produksinya}

Luas lahan rata-rata yang ditanami penduduk untuk komoditi padi adalah 0,21 ha untuk desa Sukakarya, 0,07 ha untuk desa Batulayang dan 0,22 ha untuk desa Gadog. Luas lahan rata-rata tanaman sayuran adalah 0,07 ha untuk desa Sukakarya dan 0,24 ha untuk desa Batulayang. Jenis umbi-umbian hanya ditanam oleh penduduk di desa Sukakarya yaitu dengan luas lahan rata-rata 0,11 ha, begitu juga untuk jenis tanaman kacang-kacangan yaitu seluas 0,04 ha.

Berdasarkan angka-angka konversi Soedarmo dan Sediaoetama (1977) dan neraca bahan makanan oleh Depkes RI (1983), maka produktivitas lahan di daerah penelitian dalam hal ini produktivitas bersih (netto) dapat dilihat pada Tabel 2 .

Tabel(Table) 2. Jumlah Produksi Jenis Tanaman Pangan Desa-desa Contoh di Kawasan Puncak Kabupaten Bogor (Production of food crops in sample villages in PuncakArea, Bogor District)

\begin{tabular}{|l|l|c|c|c|c|c|}
\hline No & Nama Desa & \multicolumn{5}{|c|}{ Produksi Tanaman Pangan (Food Crops Production) } \\
\cline { 3 - 7 } & $\begin{array}{c}\text { (Village) } \\
\text { Padi }\end{array}$ & $\begin{array}{c}\text { Kacang2an } \\
(\text { Reans })\end{array}$ & $\begin{array}{c}\text { Umbi-umbian } \\
(\text { Tubblers })\end{array}$ & $\begin{array}{c}\text { Sayuran } \\
\text { (Vegetables) })\end{array}$ & $\begin{array}{c}\text { Jumlah (Kkal) } \\
\text { (Total) }\end{array}$ \\
\hline 1. & Sukakarya & 1.300 .320 & 28.755 & 862.400 & 198.000 & 2.389 .475 \\
2. & Batulayang & 360.000 & 0 & 0 & $608.666,67$ & $968.666,7$ \\
3. & Gadog & 680.400 & 0 & 0 & 25.300 & 705.700 \\
\hline & Jumlah & 2.340 .720 & 28.755 & 862.400 & $831.966,67$ & $4.063 .841,7$ \\
\hline & Rata-rata & 780.240 & 9.585 & $287.466,67$ & $277.322,22$ & $1.354 .613,9$ \\
\hline
\end{tabular}

Tabel 2 menunjukkan bahwa rata-rata produksi tanaman pangan di desa-desa contoh dan setara kalorinya adalah sebesar 1.354.613,9 kkal tiap kepala keluarga petani setiap tahun. Untuk desa-desa contoh, yang memberikan sumbangan produksi tertinggi adalah padi, kemudian disusul oleh umbiumbian, sayuran dan kacang-kacangan. Berdasarkan hasil tersebut dapat diketahui bahwa produksi tanaman pangan yang dinyatakan setara kilo kalori yang tertinggi terdapat pada desa Sukakarya, kemudian berturut-turut diikuti desa Batulayang dan Gadog.

\section{B. Konsumsi Minimum dalam Menu Penduduk}

Hasil wawancara langsung dengan kepala keluarga yang terpilih menjadi responden menunjukkan bahwa pola konsumsi penduduk sebagian besar masih bertumpu pada sumber kalori dan protein yang berasal dari pertanian, terutama dari komoditas beras. Hal ini dapat dilihat dari konsumsi ke empat jenis bahan makanan dalam menu penduduk seperti pada Tabel 3.

Konsumsi minimum adalah jumlah kalori yang dikonsumsi oleh masyarakat dari jenis tanaman pangan yang ditanam di lahan pertanian, baik lahan sawah maupun lahan tegalan. Semakin banyak jenis tanaman yang dikonsumsi oleh masyarakat maka semakin tinggi konsumsi minimum masyarakat. Konsumsi minimum juga ditentukan oleh banyaknya jumlah anggota keluarga dalam rumah tangga, kebiasaan makan, tingkat pendapatan keluarga dan umur. Semakin banyak jumlah anggota keluarga dalam satu rumah tangga maka konsumsi pangan akan semakin tinggi.

Dari Tabel 3 tampak bahwa komoditi padi merupakan sumber kalori utama dalam pola makanan penduduk di desa-desa contoh. Besarnya rata-rata tingkat konsumsi padi (beras) tersebut di desa-desa contoh adalah sebesar $40,42 \%$. Angka-angka tersebut di atas juga memberikan gambaran bahwa penduduk di kawasan Puncak Kabupaten Bogor masih dominan mengkonsumsi beras untuk memenuhi kebutuhan akan pangan, sedangkan jenis bahan makanan lainnya (selain beras) hanya dijadikan sebagai makanan selingan. 
Tabel(Table)3. Tingkat konsumsi dalam menu penduduk desa-desa contoh di kawasan Puncak, Kabupaten Bogor (Consumption level in peoples menu of samplevillages in Puncak Area, Bogor District)

\begin{tabular}{|c|c|c|c|c|c|c|c|}
\hline \multirow{2}{*}{ No } & \multirow{2}{*}{$\begin{array}{l}\text { Nama Desa } \\
\text { (Village) }\end{array}$} & \multirow{2}{*}{$\begin{array}{l}\text { Total Kalori } \\
\text { dalam Menu } \\
\text { Penduduk } \\
\text { (kkal/th) } \\
\text { (Total Calorie in } \\
\text { peoples menu) }\end{array}$} & \multicolumn{5}{|c|}{$\begin{array}{l}\text { Tingkat Konsumsi Minimum untuk Jenis Tanaman yang Ditanam } \\
(\% / \text { Tahun }) \text { (Minimum consumption level for coop planted })\end{array}$} \\
\hline & & & $\begin{array}{l}\text { Beras } \\
\text { (Rice) }\end{array}$ & $\begin{array}{l}\text { Umbi- } \\
\text { umbian } \\
\text { (Tubblers) }\end{array}$ & $\begin{array}{l}\text { Kacang- } \\
\text { kacangan } \\
\text { (Beans) }\end{array}$ & $\begin{array}{c}\text { Sayuran } \\
(\text { Vegetables })\end{array}$ & $\begin{array}{l}\text { Jumlah } \\
(\text { Total })\end{array}$ \\
\hline 1. & Sukakarya & $895.466,67$ & 40,70 & 2,27 & 1,67 & 2,61 & 47,25 \\
\hline 2. & Batulayang & 924 & 39,4 & 2,20 & 1,6 & 2,52 & 45,75 \\
\hline 3. & Gadog & $885.733,33$ & 41,15 & 2,29 & 1,69 & 2,63 & 47,76 \\
\hline & Jumlah & $\begin{array}{r}2.705 .866,67 \\
90195556\end{array}$ & $\begin{array}{r}121,26 \\
4042\end{array}$ & $\begin{array}{l}6,76 \\
225\end{array}$ & 4,98 & 7,76 & $\begin{array}{r}140,76 \\
4692\end{array}$ \\
\hline
\end{tabular}

\section{Faktor Koreksi p dan k}

Dalam perhitungan daya dukung lahan terkoreksi pada rumus Bayliss-Smith digunakan besaran faktor $\mathrm{p}$ dan $\mathrm{k}$, yang berfungsi untuk mengoreksi besarnya daya dukung lahan (Agustono,1984). Kedua faktor tersebut digunakan dengan pertimbangan adanya pembagian mata pencaharian (profesi) dan konsumsi penduduk di luar sektor pertanian. Faktor p berkaitan dengan masalah kependudukan, terutama dalam hal keragaman mata pencaharian penduduk. Dalam hal ini, mata pencaharian penduduk dikelompokkan ke dalam profesi di sektor pertanian dan di luar sektor pertanian. Nilai p ditentukan oleh jumlah seluruh penduduk desa dan jumlah seluruh penduduk yang mempunyai mata pencaharian di luar sektor pertanian.

Faktor k berkaitan dengan pola konsumsi penduduk, dan nilainya ditentukan oleh besarnya pengeluaran penduduk untuk konsumsi di luar sektor pertanian dan jumlah pengeluaran untuk konsumsi dari sektor pertanian.

Dalam perhitungan besarnya daya dukung lahan, kedua faktor ini mempunyai peran dapat memperbesar nilai daya dukung lahan (berbanding lurus). Makin tinggi nilai kedua faktor ini di suatu desa, maka makin tinggi pula besarnya daya dukung lahan di desa tersebut. Sebaliknya, makin rendah nilai kedua faktor ini, makin rendah pula besarnya daya dukung lahan.

Berdasarkan hasil penelusuran data dan wawancara yang dilakukan dengan kepala keluarga yang terpilih menjadi responden di masing-masing desa contoh, diperoleh nilai faktor $\mathrm{p}$ seperti pada Tabel 4.

Dari Tabel 4 dapat diketahui bahwa nilai p di desa Sukakarya sebesar 1,99, di desa Batula yang sebesar 2,82, dan di desa Gadog sebesar 3,46. Hal ini mencerminkan bahwa di desa Gadog penduduk yang bermatapencaharian di sektor pertanian relatif lebih sedikit dibandingkan penduduk didesa Batulayang dan Sukakarya. Selanjutnya, hasil wawancara yang dilakukan dengan responden di ketiga desa, diperoleh nilai faktor k yang dapat dilihat pada Tabel 5 .

Dari Tabel 5 di atas dapat diketahui bahwa di ketiga desa contoh rata-rata nilai $\mathrm{k}$ adalah sebesar 1,39; nilai k paling tinggi terdapat di desa Sukakarya $(2,567)$, kemudian desa Gadog $(1,203)$ dan Batulayang $(0,413)$. Dari ketiga desa contoh tersebut, rata-rata pengeluaran konsumsi diluar sektor pertanian lebih besar dibandingkan dengan pengeluaran disektor pertanian, terkecuali desa Batulayang.

Pengeluaran untuk konsumsi/kebutuhan di luar sektor pertanian meliputi perabot rumah tangga, pendidikan, kesehatan, pajak, pakaian, upacara keagamaan dan lain-lain. Untuk desa Sukakarya sebesar Rp 14.587.500 per tahun, desa Batulayang Rp 7.118.013,7 per tahun dan desa Gadog sebesar Rp 11.111.290 per tahun. Pengeluaran untuk konsumsi di luar sektor pertanian lebih tinggi dibandingkan dengan konsumsi disektor pertanian, mengindikasikan bahwa penduduk desa yang bersangkutan lebih makmur dan akan meningkatkan besarnya daya dukung. 
Tabel (Table ) 4. Jumlah penduduk yang bermatapencaharian dan besarnya faktor koreksi p di desa-desa contoh di kawasan Puncak, Kabupaten Bogor pada tahun 2003 (Total population with income and correction factor p of sample villages in Puncak, Bogor District in 2003)

\begin{tabular}{|l|l|c|c|c|c|c|c|c|}
\hline \multirow{2}{*}{ No } & $\begin{array}{c}\text { Nama Desa } \\
\text { (Villages) }\end{array}$ & $\begin{array}{c}\text { Jumlah } \\
\text { Penduduk } \\
\text { (Jiwa) } \\
\text { (Total }\end{array}$ & $\begin{array}{c}\text { Penduduk } \\
\text { Bermata } \\
\text { pencaharian } \\
\text { (Population }\end{array}$ & \multicolumn{2}{|c|}{$\begin{array}{c}\text { Jumlah Penduduk } \\
\text { Berprofesi Petani } \\
\text { (Total farmers) }\end{array}$} & $\begin{array}{c}\text { Jumlah Penduduk } \\
\text { Berprofesi Non Petani } \\
\text { (Total non } \\
\text { farmers) }\end{array}$ & $\begin{array}{c}\text { Nilai } \\
\mathrm{p}\end{array}$ \\
\cline { 5 - 8 } & & Populath income) & Jiwa & $\%$ & Jiwa & $\%$ & \\
\hline 1. & Sukakarya & 4.986 & 1.124 & 563 & 11,29 & 561 & 11,25 & 1,99 \\
2. & Batulayang & 6.013 & 2.211 & 784 & 13,04 & 1.427 & 23,73 & 2,82 \\
3. & Gadog & 6.994 & 2.076 & 600 & 29,68 & 1.476 & 21,10 & 3,46 \\
\hline & Jumlah & 17.993 & 5.411 & 1.947 & 54,01 & 3.464 & 56,08 & 8,27 \\
& Rata-rata & $5.997,7$ & $1.803,7$ & 649 & 18,00 & $1.154,7$ & 18,69 & 2,76 \\
\hline
\end{tabular}

Tabel (Table) 5. Jumlah pengeluaran penduduk untuk konsumsi dan besarnya faktor koreksi k di kawasan Puncak, Kabupaten Bogor (Expenditure for consumption and corection factor $k$ in Pundak Area, Bogor District)

\begin{tabular}{|c|c|c|c|c|c|}
\hline \multirow[t]{2}{*}{ No. } & \multirow{2}{*}{$\begin{array}{c}\text { Nama Desa } \\
\text { (Villages) }\end{array}$} & \multirow{2}{*}{$\begin{array}{l}\text { Pengeluaran } \\
\text { (Rp/Th) } \\
\text { (Expenditure) } \\
(\text { IDR/Year) }\end{array}$} & \multicolumn{2}{|c|}{$\begin{array}{c}\text { Pengeluaran Konsumsi }(\mathrm{Rp} / \mathrm{Th}) \\
\text { (Expenditure for consumption) }\end{array}$} & \multirow{2}{*}{$\begin{array}{l}\text { Nilai } \mathrm{k} \\
(k \text { value })\end{array}$} \\
\hline & & & $\begin{array}{l}\text { Luar Sektor } \\
\text { Pertanian }\end{array}$ & $\begin{array}{c}\text { Sektor } \\
\text { Pertanian }\end{array}$ & \\
\hline 1. & Sukakarya & 20.269 .250 & 14.587 .500 & 5.681 .750 & 2,567 \\
\hline 2. & Batulayang & 24.352 .914 & $7.118 .013,7$ & 17.234 .900 & 0,413 \\
\hline \multirow[t]{3}{*}{3.} & Gadog & 20.347 .608 & 11.111 .290 & $9.236 .317,5$ & 1,203 \\
\hline & Jumlah & 64.969 .772 & 32.816 .804 & 32.152 .968 & 4,183 \\
\hline & Rata-rata & 21.656 .591 & 10.938 .935 & 10.717 .656 & 1,394 \\
\hline
\end{tabular}

\section{Besarnya Daya Dukung Lahan}

Dalam hubungan dengan kebutuhan manusia akan pangan diperlukan suatu batasan daya dukung lahan yang dapat menentukan jumlah penduduk yang dapat ditunjang per satuan daerah, pada tingkat tehnologi dan kehidupan tertentu. Dalam hal ini, daya dukung lahan dianggap sebagai jumlah individu yang dapat didukung oleh suatu satuan luas sumberdaya lahan dan lingkungan dalam keadaan sejahtera dan lestari. Jadi daya dukung lahan memiliki dua komponen, yaitu besarnya populasi manusia dan luas sumberdaya dan lingkungan yang dapat memberikan kesejahteraan kepada populasi manusia.

Setelah diketahui nilai-nilai dari setiap komponen yang diperlukan untuk perhitungan daya dukung lahan, kemudian dilakukan perhitungan-perhitungan dengan memasukkan nilai-nilai tersebut ke dalam rumus Bayliss-Smith yang sudah terkoreksi. Hasil dari perhitungan dengan rumus tersebut dapat diketahui jumlah manusia maksimum yang dapat ditampung oleh suatu luasan lahan (ha).

Berdasarkan perhitungan rumus Bayliss-Smith, diperoleh nilai besarnya daya dukung lahan untuk masing-masing desa contoh, seperti tertera pada Tabel 6.

Pada Tabel 6 di atas tercantum besarnya daya dukung murni dan daya dukung terkoreksi. Daya dukung murni merupakan besarnya daya dukung lahan hasil dari perhitungan dengan menggunakan rumus Bayliss-Smith yang sebenarnya, dan belum dipadukan dengan faktor koreksi $\mathrm{p}$ dan $\mathrm{k}$. Hasil perhitungan dengan rumus tersebut diperoleh angka daya dukung lahan rata-rata di desa-desa contoh, untuk desa Sukakarya sebesar 84,48 jiwa/hektar, untuk desa Batulayang sebesar 40,90 jiwa/hektar, dan desa Gadog sebesar 35,65 jiwa/hektar.

Angka-angka tersebut menerangkan apabila semua penduduk bermata pencaharian dari sektor pertanian tanaman pangan yang diteliti saja (padi, umbi-umbian, kacang-kacangan dan sayuran), serta 
pola konsumsi hanya bergantung pada hasil tanaman pangan tersebut, maka daya dukung lahan rata-rata di desa Sukakarya sebesar 84,48 jiwa/hektar, di desa Batulayang sebesar 40,90 jiwa/hektar, dan desa Gadog sebesar 35,65 jiwa/hektar. Kondisi ini dapat diberlakukan apabila kita menganggap ketiga desa tersebut masih merupakan daerah pertanian yang subsisten. Pada kenyataannya ketiga desa tersebut merupakan daerah yang berkembang dengan pesat, sehingga profesi penduduknya tidak hanya sebagai petani dan pola konsumsinya sudah beragam.

Tabel(Table) 6. Daya dukung lahan desa-desa contoh di kawasan Puncak Kabupaten Bogor (Land Carrying capacity of sample villages in Puncak Area, Bogor District)

\begin{tabular}{|l|l|c|c|c|c|c|c|}
\hline No. & $\begin{array}{c}\text { Nama Desa } \\
\text { (Village) }\end{array}$ & $\begin{array}{c}\text { Produksi } \\
\text { Pangan (kkal) } \\
\text { (Food Crops } \\
\text { production) }\end{array}$ & $\begin{array}{c}\text { Konsumsi } \\
\text { Minimum (\%) } \\
\text { (Minimum } \\
\text { consumption) }\end{array}$ & $\begin{array}{c}\text { Daya Dukung } \\
\text { Murni } \\
\text { (Pure Carrying } \\
\text { Capacity) } \\
\text { (Jiwa/ha) }\end{array}$ & $\mathrm{p}$ & $\mathrm{k}$ & $\begin{array}{c}\text { Daya Dukung } \\
\text { Terkoreksi (Jiwa/ha) } \\
\text { (Corrected carrying } \\
\text { capacity) }\end{array}$ \\
\hline 1. & Sukakarya & $5.041 .792,25$ & 47,25 & 84,48 & 1,99 & 2,57 & 432,85 \\
2. & Batulayang & $1.859 .840,06$ & 45,75 & 40,90 & 2,82 & 0,41 & 47,63 \\
3. & Gadog & $1.150 .291,00$ & 47,76 & 35,65 & 3,46 & 1,20 & 148,39 \\
\hline & Jumlah & $8.051 .923,31$ & 140,76 & 161,03 & 8,28 & 4,18 & 628,87 \\
& Rata-rata & $2.683 .974,44$ & 46,92 & 53,58 & 2,76 & 1,39 & 209,62 \\
\hline
\end{tabular}

Hasil perhitungan dengan menggunakan rumus Bayliss-Smith yang terkoreksi, menunjukkan angka daya dukung lahan rata-rata di desa-desa contoh yaitu desa Sukakarya 432,85 jiwa/hektar, desa Batulayang 47,63 jiwa/hektar dan desa Gadog sebesar 148,39 jiwa/hektar. Dengan memasukkan faktor koreksi $\mathrm{p}$ dan $\mathrm{k}$ ke dalam rumus Bayliss-Smith yang sebenarnya, tampak bahwa angka daya dukung lahan di dua desa meningkat tajam sedangkan satu desa yaitu Batulayang peningkatannya hanya sedikit (kecil). Hal ini merupakan bentuk toleransi jumlah yang diketahui dengan mempertimbangkan komponen mata pencaharian dan pola konsumsi penduduk di ketiga desa tersebut.

Hasil perhitungan daya dukung di atas bila dibandingkan dengan angka kepadatan penduduk yang sesungguhnya, maka dapat diketahui gambaran desa-desa contoh apakah kepadatan penduduknya telah atau belum melampaui daya dukung lahannya. Perbandingan besarnya daya dukung lahan dengan kepadatan penduduk yang sesungguhnya (nyata) dapat dilihat pada Tabel 7.

Tabel (Table) 7. Daya dukung lahan, kepadatan penduduk dan kepadatan agraris (Land carrying capacity, population density and agrarical density)

\begin{tabular}{|c|l|c|c|l|l|l|l|l|}
\hline No. & $\begin{array}{c}\text { Desa } \\
\text { (Village })\end{array}$ & $\begin{array}{c}\text { Luas } \\
\text { desa } \\
\text { (ha) } \\
\text { Village } \\
\text { Area) }\end{array}$ & $\begin{array}{c}\text { Luas Lahan } \\
\text { Pertanian } \\
\text { (ha) } \\
\text { (Agriculture } \\
\text { Area) })\end{array}$ & $\begin{array}{l}\text { Proporsi lahan } \\
\text { pertanian terhadap } \\
\text { luas desa (\%) } \\
\text { (Proportion of } \\
\text { agriculture area } \\
\text { to village area) }\end{array}$ & $\begin{array}{l}\text { Jumlah } \\
\text { Penduduk } \\
\text { (Jiwa) } \\
\text { (Popu- } \\
\text { lation) }\end{array}$ & $\begin{array}{l}\text { Kepadatan } \\
\text { Penduduk } \\
\text { (Jiwa/ha) } \\
\text { (Population } \\
\text { density) }\end{array}$ & $\begin{array}{l}\text { Kepadatan } \\
\text { Agraris } \\
\text { (Jiwa/ha) } \\
\text { Agro } \\
\text { density) }\end{array}$ & $\begin{array}{l}\text { Daya dukung } \\
\text { murni (Jiwa/ } \\
\text { ha) (Pure } \\
\text { carrying } \\
\text { capacity) }\end{array}$ \\
\hline 1 & Sukakarya & 339 & 245,13 & 72,31 & 4986 & 14,71 & 20,34 & 84,48 \\
\hline 2 & Batulayang & 226 & 81,99 & 36,28 & 6013 & 26,61 & 73,33 & 40,90 \\
\hline 3 & Gadog & 194 & 111,80 & 57,63 & 6994 & 36,05 & 62,56 & 35,65 \\
\hline & Rata-rata & - & - & - & - & 25,79 & 52,08 & 53,68 \\
\hline
\end{tabular}

Tabel 7 menunjukkan bahwa desa-desa contoh di Kawasan Puncak Kabupaten Bogor secara umum daya dukung lahannya belum terlampaui. Hal ini dapat dilihat pada besarnya angka rata-rata kepadatan penduduk yang sebenarnya $(25,79 \mathrm{jiwa} / \mathrm{Ha})$ lebih kecil daripada besarnya angka rata-rata daya dukung murni $(53,68 \mathrm{jiwa} / \mathrm{Ha})$ dan daya dukung terkoreksi $(209,62 \mathrm{jiwa} / \mathrm{Ha})$. Berdasarkan pada daya dukung murni, maka desa-desa contoh di kawasan Puncak tingkat kepadatannya pada saat ini hanya $48,04 \%$ dari daya dukung murni. Dengan demikian masih dapat menampung sebanyak 26 jiwa/ 
Ha. Kondisi tersebut mencerminkan bahwa desa-desa contoh tersebut masih dapat memungkinkan dikembangkannya sektor pertanian dan non pertanian. Akan tetapi harus memperhatikan sisi ekologi, hal ini untuk menghindarkan kerusakan lingkungan yang lebih parah dari kondisi yang sekarang. Hal tersebut perlu diperhatikan mengingat fungsi nilai daya dukung sebagai batasan yang memungkinkan bagi lingkungan untuk menghidupi manusia. Selain hal tersebut, perlu diperhatikan pula bahwa kepadatan penduduk yang tercantum adalah kepadatan penduduk yang tercatat belum mempertimbangkan penduduk yang keluar masuk wilayah tersebut. Sementara itu kawasan Puncak adalah wilayah tujuan wisata yang memungkinkan banyak aktivitas penduduk luar yang dilakukan di wilayah tersebut. Terutama untuk desa Gadog yang sudah melampaui daya dukung lahannya, begitu juga untuk desa Batulayang yang kepadatan penduduknya sudah mendekati daya dukung lahannya mengingat desa tersebut dekat dengan pariwisata Taman Safari Indonesia yang memungkinkan penduduk luar untuk melakukan aktivitas ekonomi di desa tersebut.

Bila dibandingkan dengan kepadatan penduduk agraris, desa yang telah melampaui daya dukungnya adalah desa Batulayang sebesar 73,33 jiwa/Ha dengan daya dukung lahan 40,90 jiwa/Ha dan desa Gadog sebesar 62,56 jiwa/Ha dengan daya dukung lahan 35,65. Sedangkan desa Sukakarya kepadatan agrarisnya masih dibawah daya dukung lahannya yaitu sebesar 20,34 jiwa/Ha dengan daya dukung lahan 84,48 jiwa/Ha. Hal yang menjadi perbedaan besarnya kepadatan penduduk wilayah dan kepadatan penduduk agraris dengan daya dukung lahan adalah adanya perbedaan luas lahan pertanian yang banyak mengalami perubahan menjadi pemukiman dan sarana lainnya. Kepadatan penduduk di desa Gadog dan Batulayang lebih besar dibandingkan dengan desa Sukakarya karena kedua desa tersebut lebih dekat dengan aktivitas ekonomi atau lebih dekat dengan perkotaan juga karena pengaruh topografi desa tersebut yang cenderung lebih datar dibandingkan dengan desa Sukakarya.

\section{KESIMPULAN}

Hasil perhitungan daya dukung murni menunjukkan daya dukung lahan di desa Sukakarya 84,48 jiwa/ha, desa Batulayang 40,90 jiwa/ha dan desa Gadog sebesar 35,65 jiwa/ha. Dengan angka kepadatan penduduk yang sesungguhnya yaitu desa Sukakarya 14,71 jiwa/ha, Batulayang 26,61 jiwa/ha dan Gadog 36,05 jiwa/ha, maka desa Gadog sudah melampaui daya dukung lahannya.

Ditinjau dari kepadatan agraris, dua desa yaitu Batulayang 73,23 jiwa/ha dan Gadog 62,56 jiwa/ha sudah melampaui daya dukungnya. Sedangkan desa Sukakarya dengan kepadatan 20,34 jiwa/ha belum melampaui daya dukung agraris.

\section{DAFTAR PUSTAKA}

Agustono. 1984. Daya Dukung Lahan dan Faktor-faktor yang Mempengaruhinya di Kabupaten Cianjur dan Karawang, Jawa Barat. Tesis. Fakultas Pasca Sarjana. IPB.

Hermanto, A. 2005. Pemanfaatan Lahan Berbasis Rencana Tata Ruang sebagai Upaya Perwujudan Ruang Hidup yang Nyaman, Produktif, dan Berkelanjutan.

Mahmudi, B. 2004. Optimalisasi Penggunaan Lahan dan Penetapan Daya Dukung Lingkungan Di Daerah Tangkapan Air (DTA) Cilampuyang Sub DAS Cimanuk Hulu, Kabupaten Garut, Propinsi Jawa Barat. Tesis. Pasca Sarjana. Institut Pertanian Bogor.

Maulana, LH. 2003. Analisis Daya Dukung Lahan dan Faktor-faktor yang Mempengaruhinya di Kawasan Puncak Wilayah Kabupaten Bogor, Jawa Barat. 
Pemerintah Kabupaten Daerah Tingkat II Bogor. 2000. Rencana Tata Ruang Wilayah Kabupaten Daerah Tingkat II Bogor. Bogor.

Rusli, S. 1997. Pengantar Ilmu Kependudukan. LP3. Jakarta.

Sayogyo, Goenardi, S. Rusli, S. Harjadi dan M. Khumaedi. 1983. Menuju Gizi Baik yang Merata di Pedesaan dan Kota. Gajah Mada University Press. Yogyakarta.

Soerianegara, I. 1978. Pengelolaan Sumberdaya Alam Bagian I dan II. Sekolah Pasca Sarjana IPB. 